\title{
Effects of long-term progesterone exposure on porcine uterine gene expression: progesterone alone does not induce secreted phosphoprotein 1 (osteopontin) in glandular epithelium
}

\author{
Daniel W Bailey ${ }^{1}$, Kathrin A Dunlap ${ }^{1}$, David W Erikson ${ }^{1}$, Atish K Patel ${ }^{1}$, Fuller W Bazer ${ }^{2}$, \\ Robert C Burghardt ${ }^{1}$ and Greg A Johnson ${ }^{1}$ \\ Departments of ${ }^{1}$ Veterinary Integrative Biosciences and ${ }^{2}$ Animal Science, Texas A\&M University, College Station, \\ Texas 77843-4458, USA
}

Correspondence should be addressed to G A Johnson; Email: gjohnson@cvm.tamu.edu

\begin{abstract}
Pigs experience significant conceptus loss near mid-gestation, correlating with increasing glandular epithelial (GE) development and secretory activity. Secreted phosphoprotein 1 (SPP1, osteopontin) increases in GE between days 30 and 40 of pregnancy and is expressed in the GE of day 90 pseudopregnant pigs, suggesting that progesterone $\left(\mathbf{P}_{4}\right)$ from corpora lutea is responsible for induction of SPP1 in GE. In this study, pigs were ovariectomized and treated daily with $\mathrm{P}_{\mathbf{4}}$ to assess effects of 40 days of $\mathrm{P}_{\mathbf{4}}$ exposure on SPP1, $\mathrm{P}_{\mathbf{4}}$ receptor (PGR), uteroferrin (ACP5), and fibroblast growth factor 7 (FGF7) expression in porcine endometria. PGR mRNA decreased in pigs injected with $P_{4}$ compared with pigs injected with corn oil (CO), and PGRs were downregulated in the luminal epithelium (LE) and GE. ACP5 mRNA increased in pigs injected with $\mathrm{P}_{4}$ compared with pigs injected with $C O$, and $A C P 5$ was induced in the GE of $\mathrm{P}_{4}$-treated pigs. FGF7 mRNA increased in pigs injected with $\mathrm{P}_{4}$ compared with pigs injected with CO, and FGF7 was induced in the LE and GE of $\mathrm{P}_{4}$-treated pigs. SPP1 mRNA was not different between pigs injected with $P_{4}$ compared with pigs injected with $C O$, and SPP1 was not present in the GE of $\mathbf{P}_{4}$-treated pigs. Therefore, long-term $\mathbf{P}_{4}$, in the absence of ovarian and/or conceptus factors, does not induce SPP1 expression in GE. We hypothesize that a servomechanism involving sequential effects of multiple hormones and cytokines, similar to those for sheep and humans, is required for GE differentiation and function, including the synthesis and secretion of SPP1.
\end{abstract}

Reproduction (2010) 140 595-604

\section{Introduction}

Progesterone $\left(\mathrm{P}_{4}\right)$ is the hormone of pregnancy in all mammals (Spencer et al. 2004). Concentrations of $P_{4}$ in peripheral blood peak with maturation of the corpus luteum $(\mathrm{CL})$ around day 15 and are maintained throughout pregnancy by ovarian and placental synthesis and secretion (Spencer et al. 2004). $P_{4}$ stimulates transformation of the endometrium into a secretory tissue to create an environment permissive to early embryonic development, implantation, placentation, and fetal/placental development (Spencer et al. 2004). Importantly, $P_{4}$ increases the expression of various uterine secretory proteins that contribute to histotroph, which supports conceptus development in pigs (Knight et al. 1974, Roberts \& Bazer 1988). The majority of histotroph is thought to be secreted by the endometrial glandular epithelium (GE). Secreted phosphoprotein 1 (SPP1, commonly referred to as osteopontin) is an accepted major constituent of histotroph that is expressed in GE coincident with long-term secretion of $\mathrm{P}_{4}$ by CLs of pigs (Garlow et al. 2002, White et al. 2005).
SPP1 is an extracellular matrix/adhesion molecule that is upregulated in the pregnant uterus and has been proposed to contribute to implantation and placentation in several mammalian species (Nomura et al. 1988, Johnson et al. 1999b, 2003a, 2003b. Apparao et al. 2001, 2003, Carson et al. 2002, Garlow et al. 2002, Kao et al. 2002, Girotti \& Zingg 2003, Joyce et al. 2005a). In pigs, estrogens secreted by the elongating day 12 conceptus induce synthesis and secretion of SPP1 by endometrial luminal epithelium (LE; Garlow et al. 2002, White et al. 2005). SPP1 then binds the integrin heterodimer $\alpha v \beta 6$ to trophectoderm (Tr) and $\alpha v \beta 3$ to uterine LE to stimulate $\operatorname{Tr}$ cell and LE cell adhesion and migration, suggesting roles to promote $\mathrm{Tr}$ migration for conceptus elongation and attachment to endometrial LE for implantation in pigs (Erikson et al. 2009).

In addition to expression in LE during the periimplantation period, total endometrial SPP1 mRNA increases 20 -fold between days 25 and 85 of pregnancy due to induction of SPP1 expression in the GE, which is delayed until between days 30 and 35 of pregnancy 
when placental growth and placentation are key events in pig pregnancy (Garlow et al. 2002). SPP1 is also expressed in the GE of day 90 pseudopregnant pigs, suggesting that maintenance of secretion of $\mathrm{P}_{4}$ by CLs may be responsible for induction of SPP1 in GE (White et al. 2005). Indeed, $\mathrm{P}_{4}$ induces expression of SPP1 in the GE of sheep and rabbits (Johnson et al. 2000, Apparao et al. 2003) and induces SPP1 synthesis by human Ishikawa cells (Apparao et al. 2001). We hypothesized that $\mathrm{P}_{4}$ induces SPP1 expression in pig GE after day 30 of pregnancy.

However, estrogens, interferons (IFNs), and prolactin (PRL) have the potential to interact with $\mathrm{P}_{4}$ to influence GE synthesis of SPP1. The first trimester of pregnancy in pigs is complex and incorporates the overlapping events of conceptus elongation, pregnancy recognition signaling, and endometrial remodeling for implantation and placentation. Pregnancy recognition is the result of conceptus secretion of estrogens on days 11 and 12 of pregnancy to redirect PGF secretion from the uterine vasculature to the uterine lumen. In addition to pregnancy recognition, conceptus estrogens modulate uterine gene expression that is essential for conceptus development and implantation (Geisert et al. 1982, Ross et al. 2007, Johnson et al. 2009). Pig Tr also secretes IFNs, both the type I IFN $\delta$ and the type II IFN $\gamma$ during the peri-implantation period (La Bonnardière et al. 1991, Lefèvre et al. 1998, Joyce et al. 2007). In contrast to sheep, in which the type I IFN $\tau$ is the signal for maternal recognition of pregnancy (Bazer et al. 2009), pig conceptus IFNs have yet to be shown to influence pregnancy recognition. However, paracrine effects for IFNs are to increase the expression of several known IFN-responsive genes in the endometrium (Johnson et al. 2009). Finally, other hormones, such as PRL, may work in conjunction with $\mathrm{P}_{4}$ to regulate GE expression of SPP1 (Young et al. 1990). Ovariectomized ewes treated with $\mathrm{P}_{4}$ and placental lactogen exhibit increased GE development and SPP1 mRNA expression over ovariectomized ewes treated with $\mathrm{P}_{4}$ alone (Spencer et al. 1999). Furthermore, both pregnant and pseudopregnant pigs express SPP1 in GE and have similar concentrations of $\mathrm{PRL}$, and endometrial PRL receptors (Kensinger et al. 1986, Young et al. 1990).

Therefore, in this study, gilts were ovariectomized and treated daily with $\mathrm{P}_{4}$ for 40 days to assess the effects of $\mathrm{P}_{4}$ on SPP1 expression in porcine endometrial GE in the absence of ovarian or conceptus factors. The expression of three additional genes was assessed in these tissues. $\mathrm{P}_{4}$ receptors (PGRs) downregulate in endometrial epithelia in response to $\mathrm{P}_{4}$ treatment and served as an index of $\mathrm{P}_{4}$ 's ability to negatively regulate GE gene expression in this study (Ka et al. 2007). There were no previous reports of PGR localization in the endometrium of day 40 pregnant pigs or in ovariectomized pigs treated long-term with $\mathrm{P}_{4}$. Acid phosphate 5, tartrate resistant (ACP5, commonly referred to as uteroferrin), is induced in pig GE during the late luteal phase in response to $\mathrm{P}_{4}$ treatment and served as an index of $\mathrm{P}_{4}$ 's ability to positively regulate early pregnancy GE gene expression in this study (Chen et al. 1973, Knight et al. 1973, Schlosnagle et al. 1974, Renegar et al. 1982). Fibroblast growth factor 7 (FGF7, commonly referred to as keratinocyte growth factor) is similar to SPP1 in that it is induced in the GE of pigs between days 30 and 40 of pregnancy, and served as an index of $\mathrm{P}_{4}$ 's ability to positively regulate GE gene expression beyond the peri-implantation period (Ka et al. 2000). The hormonal regulation of FGF7 expression in pig GE was previously unknown.

\section{Results}

Figure 1 illustrates effects of long-term $\mathrm{P}_{4}$ exposure to increase hypertrophy and hyperplasia of the uterine wall of ovariectomized pigs as compared with treatment with corn oil (CO).

\section{Long-term $\mathrm{P}_{4}$ supports downregulation of PGR in endometrial LE and GE}

Slot blot hybridization revealed that steady-state levels of endometrial $P G R$ mRNA decreased in pigs injected with $\mathrm{P}_{4}$ compared with pigs injected with $\mathrm{CO}(P<0.01$; Fig. 2A). Results of in situ hybridization analysis revealed that $P G R$ mRNA was expressed in the $L E, G E$, and stroma of CO-treated pigs, but expression was limited to the stromal cells of $\mathrm{P}_{4}$-treated pigs (Fig. 2B). Therefore, an effect of long-term $\mathrm{P}_{4}$ was the expected downregulation of PGR in endometrial LE and GE.

\section{Long-term $\mathrm{P}_{4}$ supports induction of ACP5 in endometrial $G E$}

Slot blot hybridization revealed that steady-state levels of endometrial ACP5 mRNA increased in pigs injected with $\mathrm{P}_{4}$ compared with pigs injected with $\mathrm{CO}(P<0.01$; Fig. $3 \mathrm{~A})$. ACP5 $\mathrm{mRNA}$ and protein were localized in the endometrial GE of $\mathrm{P}_{4}$ - but not CO-treated pigs (Fig. 3B and $\mathrm{C}$ ). Immunoreactive proteins of $\sim 37-38 \mathrm{kDa}$ were detected in the uterine flushings of $\mathrm{P}_{4}$-treated pigs (Fig. 3D). Therefore, a second effect of long-term $\mathrm{P}_{4}$ was the expected induction of ACP5 synthesis and secretion from endometrial GE.

\section{Long-term $\mathrm{P}_{4}$ supports induction of FGF7 in endometrial LE and GE}

Slot blot hybridization revealed that steady-state levels of endometrial FGF7 mRNA increased in pigs injected with $\mathrm{P}_{4}$ compared with pigs injected with $\mathrm{CO}(P<0.01$; Fig. 4A). FGF7 mRNA was localized in both the endometrial LE and GE of $\mathrm{P}_{4^{-}}$but not CO-treated pigs (Fig. 4B). 


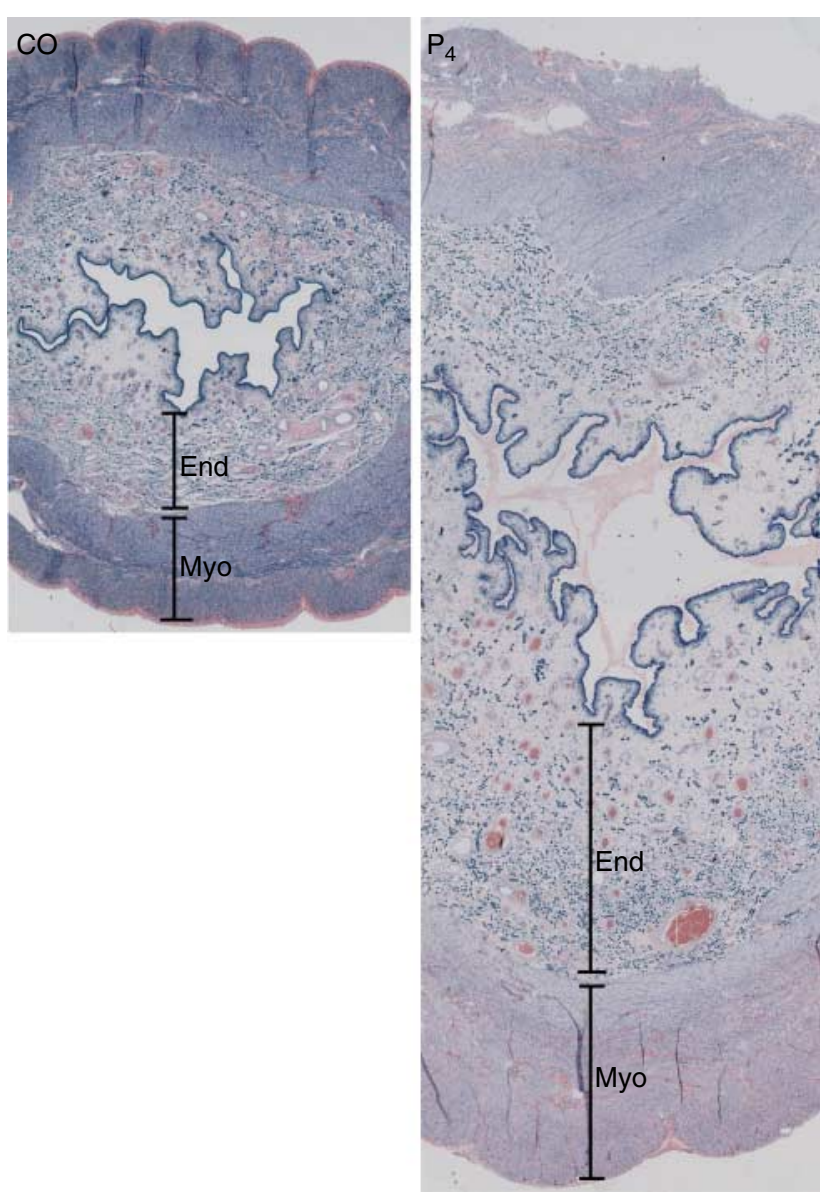

Figure 1 Gross histological effects of progesterone on pig uteri. Representative uterine cross sections from corn oil (CO)- and progesterone $\left(\mathrm{P}_{4}\right)$-treated gilts stained with Mayer hematoxylin and eosin. Note that on qualitative observation, it is evident that there is an increased area of the lumen as well as thickness of the endometrium (End) and myometrium (Myo) in response to long-term treatment with progesterone. Histotroph is also seen in the uterine lumen of pigs after long-term treatment with progesterone.

Therefore, additional effect of long-term $\mathrm{P}_{4}$ was the expected induction of FGF7 expression in endometrial $\mathrm{LE}$, and the hypothesized induction of FGF7 in GE by $\mathrm{P}_{4}$.

\section{Long-term $\mathrm{P}_{4}$ does not support induction of SPP1 in endometrial $G E$}

Slot blot hybridization revealed that steady-state levels of endometrial SPP1 mRNA were not different between pigs injected with $\mathrm{P}_{4}$ compared with pigs injected with CO ( $P>0.01$; Fig. 5A). In situ hybridization indicated that SPP1 mRNA was not present in endometrial GE of either $\mathrm{P}_{4}$ - or CO-treated pigs (Fig. 5B). In agreement with mRNA data, little to no immunoreactive SPP1 protein was detected in uterine flushings from $\mathrm{P}_{4}$-treated pigs (Fig. 5C). Therefore, contrary to our hypothesis, longterm $\mathrm{P}_{4}$, in the absence of ovarian and/or conceptus factors, did not affect SPP1 expression in GE.

\section{Discussion}

It is generally accepted that endometrial LE and GE synthesize and secrete histotroph that facilitates conceptus elongation, implantation, placentation, and fetal growth and development. We examined the effects of daily exposure to $\mathrm{P}_{4}$ for 40 days on the expression of four epithelial genes in ovariectomized pigs. In this study, long-term $\mathrm{P}_{4}$, in the absence of conceptus or ovarian factors, 1 ) was sufficient to support initial gene regulatory events that occur during the late luteal phase and the peri-implantation period of intact cyclic and pregnant pigs including downregulation of PGR in LE and GE, and induction of ACP5 in GE (Chen et al. 1973, Schlosnagle et al. 1974, Geisert et al. 1994); but 2) disregulated some delayed gene expression that occurs after day 30 of pregnancy including induction of SPP1 in GE (Garlow et al. 2002, White et al. 2005). Notably, FGF7 has a similar pattern of GE expression to SPP1 during pig pregnancy, but diverged from SPP1 in its endocrine regulation in that it was induced in GE by long-term $\mathrm{P}_{4}$ (Ka et al. 2000). Collectively, these results suggest that the hormonal milieu necessary for the production of histotroph varies for its individual components, and that genes that delay expression in GE until after the peri-implantation period may require specific servomechanisms of sequential exposure of the pregnant endometrium to ovarian, conceptus/placental, and/or uterine factors that may include $\mathrm{P}_{4}$, estrogens, IFNs, and PRL (Young et al. 1990, Spencer et al. 2004, Johnson et al. 2009).

In several species, downregulation of PGR in uterine $\mathrm{GE}$ is required for induction of secretory protein gene expression by $\mathrm{P}_{4}$ in the same epithelia (Bazer et al. 2009). This also occurs in pigs. Initial temporal and spatial localization of PGR in pig endometria established that PGR decreases in LE and GE during the luteal phase (Geisert et al. 1994); subsequent ovariectomy and hormone replacement experiments also confirmed that $\mathrm{P}_{4}$ downregulates PGR by day 15 (Ka et al. 2007). Temporal and spatial expression of PGR in pig endometrium beyond day 20 of pregnancy has not been reported. Results of this study confirm that long-term $\mathrm{P}_{4}$ exposure continues to prevent PGR expression in LE and GE, which may allow for continued and increased expression of genes for secretory proteins such as ACP5 in GE (Schlosnagle et al. 1974, Renegar et al. 1982).

ACP5 is an established $\mathrm{P}_{4}$-induced secretory product of pig GE. In pigs, ACP5 increases in uterine secretions between days 12 and 16 in response to luteal phase levels of $\mathrm{P}_{4}$, and is produced in large amounts at mid-pregnancy when secretion can exceed $1 \mathrm{~g}$ /day. Endometrial secretion of ACP5 can be maintained in ovariectomized, $\mathrm{P}_{4}$-treated (daily) pigs for 60 days (Chen et al. 1973, Schlosnagle et al. 1974, Renegar et al. 1982). As a basic glycoprotein contains one molecule of iron and possesses tartrate-resistant acid phosphatase activity 


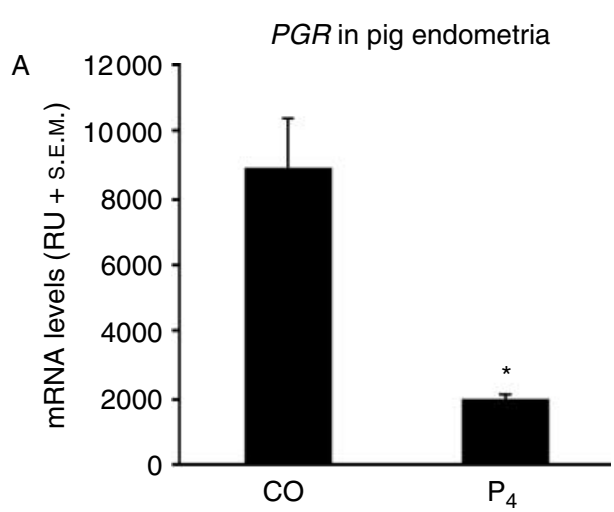

B

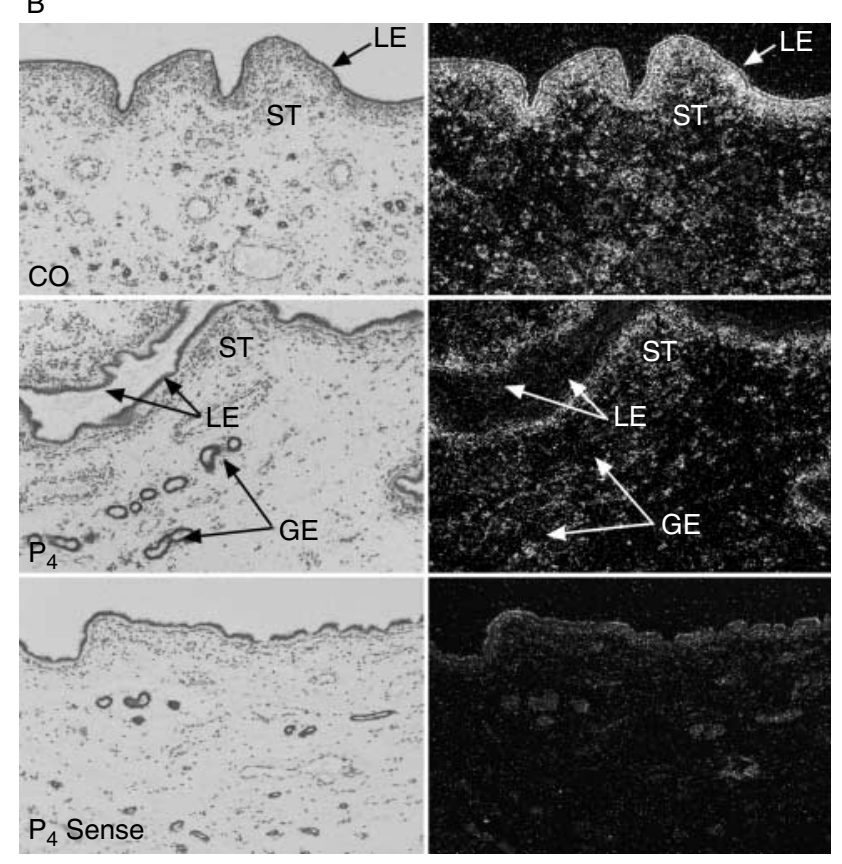

Figure 2 Long-term progesterone supports downregulation of $P G R$ in endometrial LE and GE. (A) Steady-state levels of mRNA for PGR in endometria of pigs treated with corn oil (CO) and progesterone $\left(\mathrm{P}_{4}\right)$. The mRNA levels, expressed as least square means of relative units of counts per minute with overall S.E.M., are normalized for differences in sample loading using $18 \mathrm{~S}$ rRNA and represent $20 \mu \mathrm{g}$ of total endometrial mRNA per sample. ${ }^{*} P<0.05$. (B) In situ hybridization analysis of $P G R$ mRNA in cross sections of pig endometria.

Corresponding bright-field and dark-field images from $\mathrm{CO}$ - and $\mathrm{P}_{4}$-treated pigs are shown. A representative endometrial section from a $\mathrm{P}_{4}$-treated pig hybridized with radiolabeled sense cRNA probe (Sense) served as a negative control. Width of each field is $940 \mu \mathrm{m}$. LE, luminal epithelium; $\mathrm{GE}$, glandular epithelium; ST, stratum compactum stroma.

ACP5 functions in iron transport from mother to fetal-placental unit and has hematopoietic growth factor activity (Chen et al. 1973, Roberts \& Bazer 1980, Renegar et al. 1982, Bazer et al. 1991). Results of this study confirm that long-term $\mathrm{P}_{4}$ exposure alone can maintain high levels of ACP5 synthesis and secretion from GE throughout the first trimester of pig pregnancy.
The pig endometrium is unique in that FGF7 is expressed by the LE and GE rather than by cells of mesenchymal (stromal) origin, as observed in endometria of other species (Cooke et al. 1998, Ka et al. 2000). FGF7 is expressed in the endometrial epithelia of pigs; its receptor, FGFR2, is present in both the endometrial epithelia and conceptus Tr, and FGF7 stimulates the Tr, but not endometrial epithelial cells, to undergo proliferation and differentiation. Therefore, FGF7 is proposed to be a paracrine mediator of interactions between the uterus and the conceptus (Ka et al. 2000, 2001, Ka \& Bazer 2005). FGF7 mRNA is induced in LE between days 12 and 15 of the estrous cycle and pregnancy, but GE expression is delayed until days 30 and 40 of pregnancy (Ka et al. 2000). The induction and expression of FGF7 in pig LE appears to be very complex. Ka et al. (2007) reported that FGF7 is similar to ACP5 in that its induction requires that $\mathrm{P}_{4}$ downregulates $\mathrm{PGR}$, thereby eliminating PGR-dependent inhibition of expression of most $\mathrm{P}_{4}$-regulated genes. They further postulated that endocrine effects of $\mathrm{P}_{4}$ in inducing the expression of FGF7 in endometrial LE were mediated by a paracrineacting factor(s) (progestamedin) produced by the PGRpositive stromal cells. Finally, they showed that estrogen produced by pig conceptuses binds to ESR1 in the LE to induce the maximal levels of FGF7 expression observed on day 12 of pregnancy (Ka et al. 2007). The hormonal regulation of FGF7 in pig GE had not been reported. Results of this study are novel in that long-term $\mathrm{P}_{4}$ exposure, in the absence of estrogens, induced very high expression of FGF7 in LE. This high expression contrasts with pregnancy, in which LE expression of FGF7 is minimal after day 30 (Ka et al. 2000). Clearly, an unidentified ovarian or placental factor(s) and/or physical cellular responses to attachment with $\operatorname{Tr}$ for placentation are involved in reducing FGF7 expression in LE. Long-term $\mathrm{P}_{4}$ alone supported induction of FGF7 in GE. It remains to be determined what physiological, cellular, and molecular interactions between cell types within the uterine endometrium are responsible for the delay in FGF7 production by GE until after day 30 of pregnancy in the pig.

A cursory inspection of the temporal and spatial expression of FGF7 and SPP1 in the uteri of pigs led to the assumption that these two genes were regulated similarly during pregnancy. Both genes increase in the LE during the peri-implantation period, and then in the GE after day 30 of pregnancy (Ka et al. 2000, Garlow et al. 2002). However, previous reports by White et al. (2005) and Ka et al. (2007) showed that LE expression of these two genes is different. While FGF7 requires the permissive actions of $\mathrm{P}_{4}$ for induction, and estrogen to increase expression to maximal levels, SPP1 is induced by conceptus estrogens in LE directly adjacent to the implanting conceptus where it potentially binds $\alpha v \beta 3$ integrin at the apical surface of LE and $\alpha v \beta 6$ on $\mathrm{Tr}$ to mediate attachment for implantation in pigs 


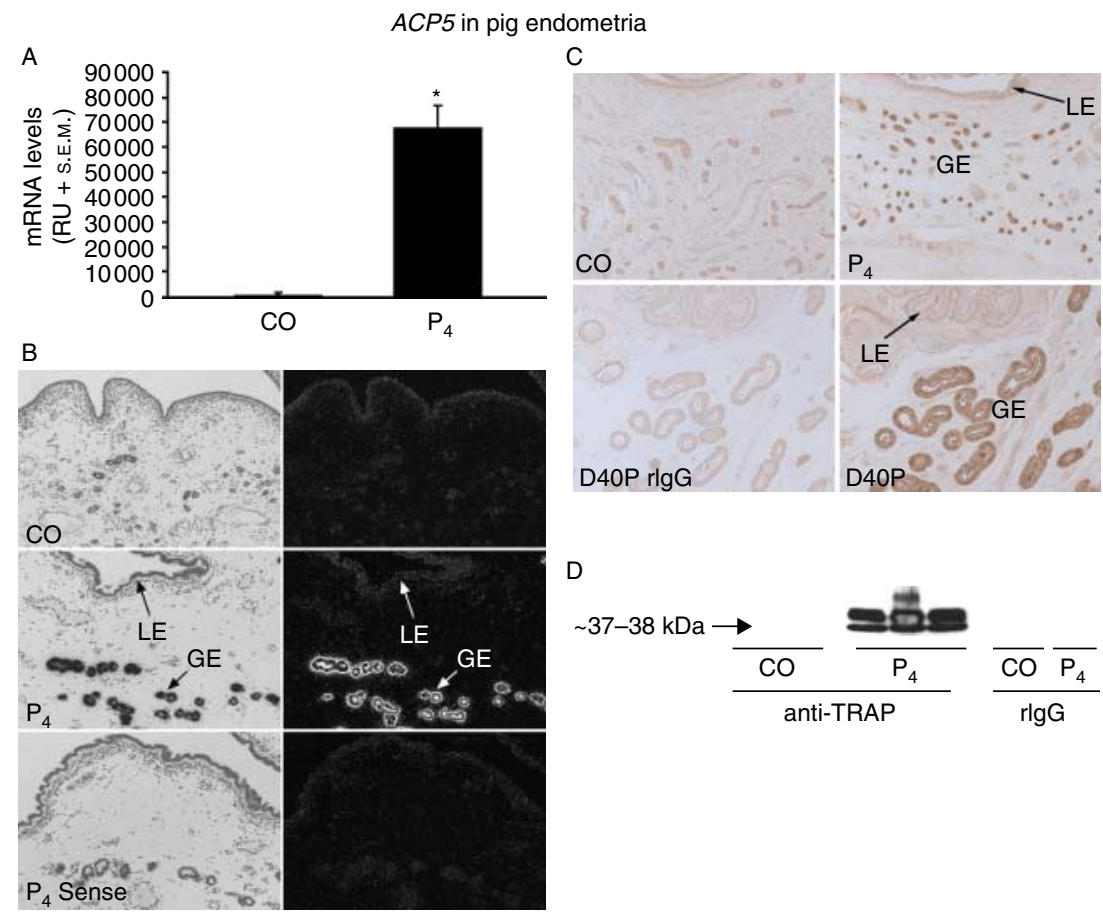

Figure 3 Long-term progesterone supports induction of ACP5 in endometrial GE. (A) Steady-state levels of mRNA for ACP5 in endometria of pigs treated with corn oil $(\mathrm{CO})$ and progesterone $\left(\mathrm{P}_{4}\right)$. The mRNA levels, expressed as least square means of relative units of counts per minute with overall S.E.M., are normalized for differences in sample loading using $18 \mathrm{~S}$ rRNA and represent $20 \mu \mathrm{g}$ of total endometrial mRNA per sample. ${ }^{*} P<0.05$.

(B) In situ hybridization analysis of ACP5 mRNA in cross sections of pig endometria. Corresponding bright-field and dark-field images from CO- and $\mathrm{P}_{4}$-treated pigs are shown. A representative endometrial section from a $\mathrm{P}_{4}$-treated pig hybridized with radiolabeled sense cRNA probe (Sense) served as a negative control. (C) Immunohistochemical analysis of ACP5 in cross sections of pig endometria. Immunoreactive ACP5 protein was detected in the GE of $\mathrm{P}_{4}$-treated pigs, but not in the GE of CO-treated pigs. Immunostaining in the GE of a day 40 pregnant pig serves as a reference for normal pregnancy expression of ACP5. Normal rabbit IgG was substituted for primary antibody as the control. Sections were not counterstained. Width of each field is $940 \mu \mathrm{m}$. LE, luminal epithelium; GE, glandular epithelium. (D) Western blot analysis (under reducing conditions) of uterine secretions from $\mathrm{CO}$ - and $\mathrm{P}_{4}$-treated pigs. Normal rabbit IgG was substituted for primary antibody as the control. Two isoforms of ACP5 protein of $\sim 37$ and $38 \mathrm{kDa}$ were detected in uterine secretions from $\mathrm{P}_{4}$-treated pigs only.

(White et al. 2005, Ka et al. 2007, Erikson et al. 2009). It was therefore expected that long-term $\mathrm{P}_{4}$ exposure, in the absence of estrogens, would not induce SPP1 expression in LE, and this was true in this study. SPP1 is also expressed in GE after day 30 of pregnancy (Johnson et al. 1999b). Direct hormonal regulation of SPP1 in pig GE had not been reported; however, day 90 pseudopregnant pigs express SPP1 in GE (White et al. 2005). The most intriguing results of this study are that long-term $\mathrm{P}_{4}$ did not induce GE expression of SPP1. Indeed, the divergence in regulation of SPP1 and FGF7 by $\mathrm{P}_{4}$ is surprising, and suggests that gene regulation in GE after day 30 of pregnancy is complex and gene specific. At the time that SPP1 begins to be expressed in GE, the endometrial glands are undergoing extensive hyperplasia and hypertrophy. The GE remain simple, coiled, and tubular until day 30 of pregnancy, but shows numerous characteristics of high secretory activity by day 35 . By mid-pregnancy, the lumens of uterine glands are greatly enlarged and filled with secretory products (Perry \& Crombie 1982, Sinowatz \& Friess 1983). During early pregnancy, the pig uterus secretes only moderate levels of histotroph, but total uterine secretions increase dramatically after day 30 of pregnancy (Knight et al. 1974, Schlosnagle et al. 1974, Basha et al. 1980). Although progress has been made toward deciphering the mechanism(s) through which $\mathrm{P}_{4}$ influences endometrial GE development in other species, these processes are poorly understood in pigs. In sheep, it is known that upregulation of SPP1 in uterine GE coincides with the $\mathrm{P}_{4}$-induced downregulation of $P G R$ after days 11 and 12 of pregnancy (Johnson et al. 2000). Furthermore, maximal SPP1 mRNA expression in GE is attained after sequential exposure to IFN $\tau, \mathrm{P}_{4}$, and placental lactogen in what has been termed a servomechanism (Spencer et al. 1999). In pigs, however, induction of SPP1 in GE is delayed over 20 days after the initial downregulation of $P G R$, and a servomechanism similar to that for sheep and humans has not been defined (Spencer et al. 1999, Garlow et al. 2002, Burton et al. 2007).

Results of this study, and those of a previous study that examined SPP1 expression in pseudopregnant pigs (White et al. 2005), are the first to clearly indicate that GE expression of SPP1 in pigs may be the result of an 


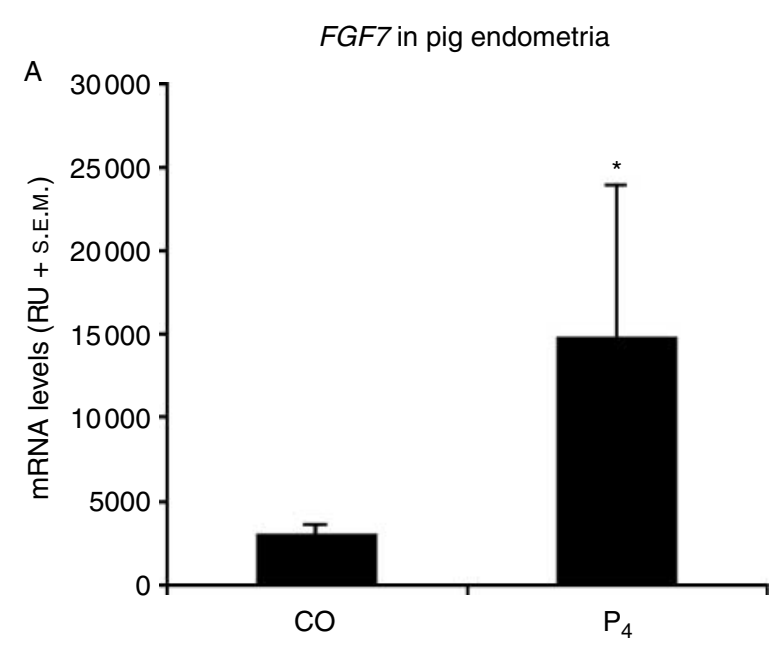

B

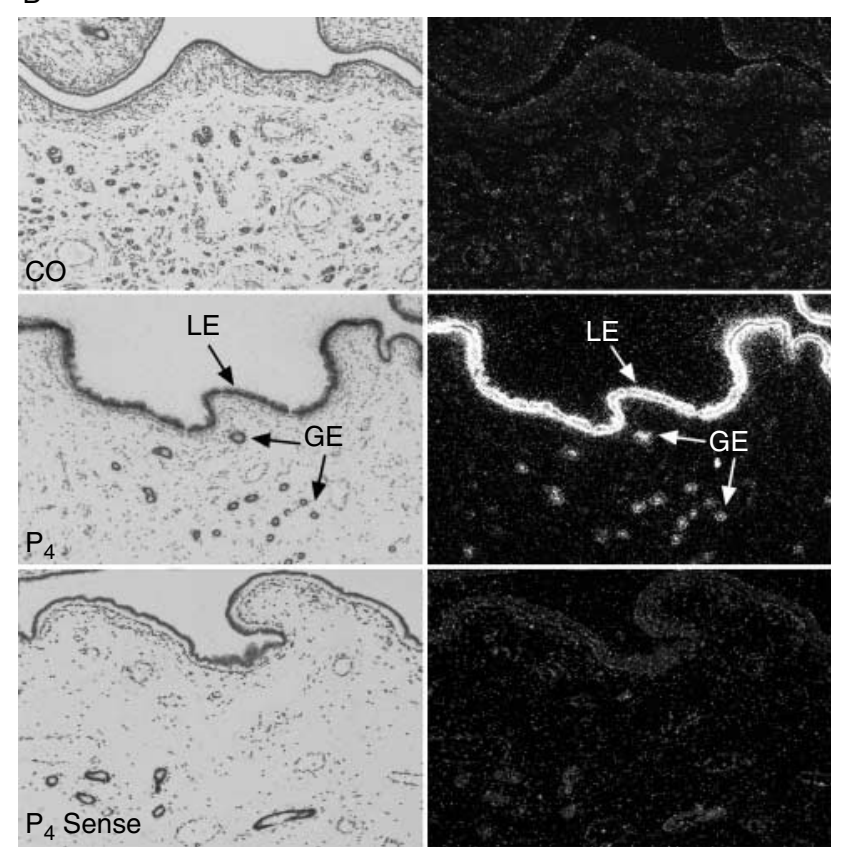

Figure 4 Long-term progesterone supports induction of $F G F 7$ in endometrial LE and GE. (A) Steady-state levels of mRNA for FGF7 in endometria of pigs treated with corn oil $(\mathrm{CO})$ and progesterone $\left(\mathrm{P}_{4}\right)$.

The mRNA levels, expressed as least square means of relative units of counts per minute with overall S.E.M., are normalized for differences in sample loading using $18 \mathrm{~S}$ rRNA and represent $20 \mu \mathrm{g}$ of total endometrial mRNA per sample. ${ }^{*} P<0.05$. (B) In situ hybridization analysis of FGF7 mRNA in cross sections of pig endometria. Corresponding bright-field and dark-field images from CO- and $\mathrm{P}_{4}$-treated pigs are shown. A representative endometrial section from a $\mathrm{P}_{4}$-treated pig hybridized with radiolabeled sense cRNA probe (Sense) served as a negative control. Width of each field is $940 \mu \mathrm{m}$. LE, luminal epithelium; GE, glandular epithelium.

undefined hormonal servomechanism, and allow us to begin to predict the identity of some of the factors involved in this servomechanism for GE function in pigs. White et al. reported that SPP1 is present in the GE of day 90 pseudopregnant pigs, generated by the injection of estradiol benzoate on days 11-15 of the estrous cycle. From these data, it was reasonably concluded that maintenance of $\mathrm{CL} \mathrm{P} \mathrm{P}_{4}$ secretion was, at least in part, responsible for induction of SPP1 in GE (White et al. 2005). However, results presented in this study clearly show that $\mathrm{P}_{4}$ alone did not induce SPP1 expression in pseudopregnant pig GE, and suggest that the treatment of pigs with estrogen (days 11-15) may be necessary for the later (days 30-40) expression of SPP1. Furthermore, because pseudopregnant pigs have intact ovaries, these ovaries might provide additional estrogens that modulate GE gene expression, and other unidentified factors that may stimulate PRL release for binding to PRL receptors in pig endometrium (Knight et al. 1973, Young et al. 1990). Therefore, SPP1 induction in GE may be the result of complex temporal interactions between effects of conceptus estrogens, unidentified ovarian factors, and $\mathrm{CL}_{4}$ on the pig endometrium.

Pigs experience two periods of significant loss of conceptuses. The first occurs during the attachment phase of the peri-implantation period and involves 30\% of conceptuses. The second involves $10-15 \%$ of the remaining conceptuses and occurs during early to midgestation (Pope 1994). This second period of conceptus loss correlates with increasing GE development, endometrial secretory activity, placental growth and differentiation, and fetal growth (Knight et al. 1974, 1977, Perry \& Crombie 1982, Sinowatz \& Friess 1983, Dwyer et al. 1994). Much is not understood about the mechanisms that underlie these waves of conceptus loss. SPP1 in the pig offers an excellent model to study these mechanisms because of its regulated and prominent LE and GE expression during these two critical periods in a species that depends significantly on histotroph throughout pregnancy (Garlow et al. 2002, White et al. 2005, Erikson et al. 2009).

\section{Materials and Methods}

\section{Animals, experimental design, and tissue collection}

Sexually mature gilts of similar age, weight, and genetic background were observed daily for estrus (day 0 ) and exhibited at least two estrous cycles of normal duration (18-21 days) before being used in these studies. All experimental and surgical procedures were in compliance with the Guide for Care and Use of Agricultural Animals in Teaching and Research and approved by the Institutional Animal Care and Use Committee of Texas A\&M University.

To evaluate the effects of long-term $\mathrm{P}_{4}$ treatment without effects of ovarian or conceptus factors on uterine epithelia, gilts were ovariectomized on day 12 of the estrous cycle and assigned randomly to receive daily injections (i.m.) of either $4 \mathrm{ml} \mathrm{CO}$ or $200 \mathrm{mg} \mathrm{P}_{4}(200 \mathrm{mg}$ in $4 \mathrm{ml} \mathrm{CO})$ on days 12 through 39 post estrus ( $n=4 /$ treatment). All gilts were hysterectomized on day 40 post estrus. Uterine flushings were obtained by introducing and recovering $40 \mathrm{ml}$ sterile Hanks balanced salt solution (Sigma Chemical Co.) from 


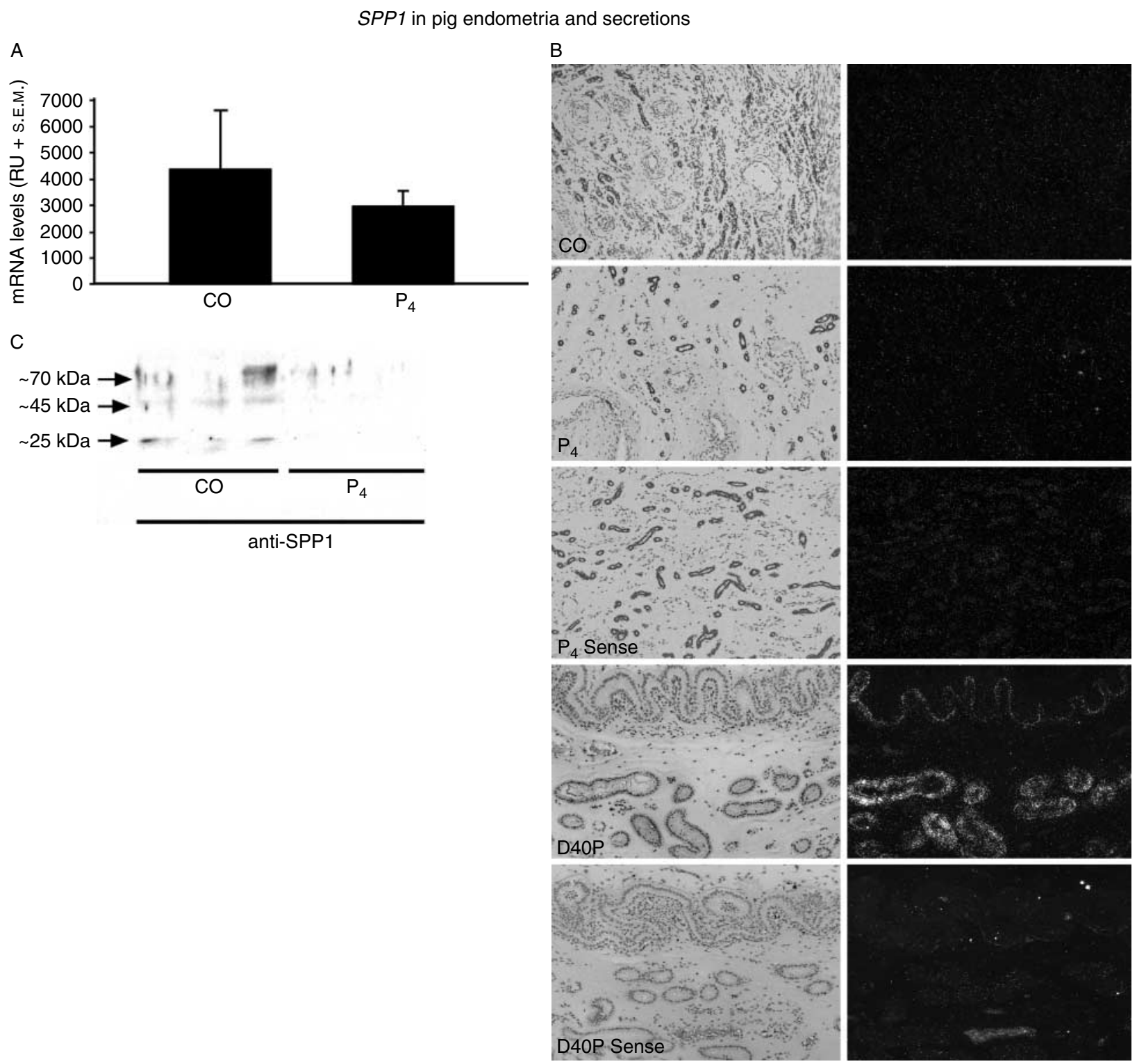

Figure 5 Long-term progesterone does not support induction of SPP1 in endometrial GE. (A) Steady-state levels of mRNA for SPP1 in endometrium of pigs treated with corn oil $(\mathrm{CO})$ and progesterone $\left(\mathrm{P}_{4}\right)$. The mRNA levels, expressed as least square means of relative units of counts per minute with overall S.E.M., are normalized for differences in sample loading using $18 \mathrm{~S}$ rRNA and represent $20 \mu \mathrm{g}$ of total endometrial mRNA per sample. (B) In situ hybridization analysis of SPP1 mRNA in cross sections of pig endometria. Corresponding bright-field and dark-field images from CO- and $\mathrm{P}_{4}$-treated pigs are shown. Sections from day 40 of pregnancy (D4OP) are shown as examples of SPP1 expression in GE. Representative endometrial sections from a $\mathrm{P}_{4}$-treated and a D40P pig hybridized with radiolabeled sense cRNA probe (Sense) served as negative controls. Width of each field is $940 \mu \mathrm{m}$. GE, glandular epithelium. (C) Western blot analysis (under reducing conditions) of SPP1 in uterine secretions from CO- and $\mathrm{P}_{4}$-treated pigs.

Immunoreactive proteins were detected using either polyclonal rabbit anti-hSPP1 (LF-123 and LF-124; Fisher et al. 1995) or rabbit IgG (rlgG) as a control (see Fig. 3D). Three forms of SPP1 of $\sim 25,45$, and $70 \mathrm{kDa}$ were detected at either very low levels or were not detected in uterine secretions from both $\mathrm{CO}$ - and $\mathrm{P}_{4}$-treated pigs.

the uterine lumen before hysterectomy. The uterine flushings were cleared of cellular debris by centrifugation (3000 $\boldsymbol{g}$ for $10 \mathrm{~min}$ at $4{ }^{\circ} \mathrm{C}$ ) and frozen at $-80{ }^{\circ} \mathrm{C}$ until analyzed. To confirm the effects of pregnancy and compare these with the effects of long-term $\mathrm{P}_{4}$ treatment on expression of ACP5 and SPP1, four gilts were bred when detected in estrus and 12 and $24 \mathrm{~h}$ thereafter. Gilts were then ovariohysterectomized on day 40 of pregnancy. From all gilts, several sections (thickness $\sim 1-1.5 \mathrm{~cm}$ ) from the middle of each uterine horn were placed in fresh $4 \%$ paraformaldehyde fixative for $24 \mathrm{~h}$ and then embedded in Paraplast Plus (Oxford Labware, St Louis, MO, USA). A sample of endometrium from each gilt was dissected from myometrium, frozen in liquid nitrogen, and stored at $-80{ }^{\circ} \mathrm{C}$ for RNA and protein extraction. 


\section{Histology}

Embedded tissues were sectioned $(5 \mu \mathrm{m})$, deparaffinized, and stained with Mayer hematoxylin and eosin for general histomorphological evaluation.

\section{Slot blot hybridization}

Steady-state levels of mRNA in porcine endometria were assessed by slot blot hybridization as described previously (Johnson et al. 1999a). Radiolabeled antisense cRNA probes were generated by in vitro transcription using linearized plasmid template, RNA polymerases, and $\left[\alpha_{-}{ }^{32} \mathrm{P}\right]-U T P$. Plasmids included a partial-length ovine PGR cDNA (Spencer et al. 1995), a partial-length porcine FGF7 CDNA (Ka et al. 2000), and a full-length porcine SPP1 cDNA (Wrana et al. 1989). A partial cDNA for porcine ACP5 mRNA was amplified by RT-PCR using total RNA from day 40 pregnant porcine endometrial tissues using the specific; forward, $5^{\prime}$-ccagaaccaacaccaggact- $3^{\prime}$; reverse, 5'-ggtagtaagggctggggaag- $3^{\prime}$. A partial porcine ACP5 cDNA was cloned into pCRII using a T/A Cloning kit (Invitrogen) and the sequence verified using an ABI PRISM Dye Terminator Cycle Sequencing kit and ABI PRISM automated DNA sequencer (Perkin-Elmer Applied Biosystems, Waltham, MA, USA). Denatured total endometrial RNA $(20 \mu \mathrm{g})$ from each gilt was hybridized with radiolabeled cRNA probes. To correct for variation in total RNA loading, a duplicate RNA slot membrane was hybridized with radiolabeled antisense 18S cRNA (pT718S; Ambion, Austin, TX, USA). After washing, the blots were digested with RNase A and radioactivity associated with slots quantified using a Typhoon 8600 Multilmager (Molecular Dynamics, Piscataway, NJ, USA). The mRNA levels were expressed as least square means of relative units (RU) of counts per minute with overall S.E.M., and differences in sample loading were normalized using $18 \mathrm{~S}$ rRNA.

\section{In situ hybridization}

Cell-specific expression of mRNAs in sections $(5 \mu \mathrm{m})$ of the porcine uterine endometria (tissue from three paraffin blocks) was determined by radioactive in situ hybridization analysis as described previously (Johnson et al. 1999a). Sections from three independent paraffin blocks from each animal were analyzed. Radiolabeled antisense or sense cRNA probes were generated by in vitro transcription using linearized plasmid template, RNA polymerases, and $\left[\alpha^{-35} \mathrm{~S}\right]-$ UTP. Deparaffinized, rehydrated, and deproteinated uterine tissue sections were hybridized with radiolabeled antisense or sense cRNA probes. After hybridization, washing, and RNase A digestion, slides were dipped in NTB-2 liquid photographic emulsion (Kodak) and exposed at $4{ }^{\circ} \mathrm{C}$ for $7-10$ days. Slides were developed in Kodak D-19 developer, counterstained with Gill's hematoxylin (Fisher Scientific, Fairlawn, NJ, USA), and then dehydrated through a graded series of alcohol to xylene. Coverslips were then affixed with Permount (Fisher Scientific). Digital images of representative fields were recorded under bright-field or dark-field illumination and evaluated using an Axioplan 2 microscope (Carl Zeiss, Thornwood, NY, USA) interfaced with an Axioplan HR digital camera and Axiovision 4.3 software. Photographic plates were assembled using Adobe Photoshop (version 6.0, Adobe Systems Inc.).

\section{Western blot analyses}

Protein concentrations in uterine flushings were determined using the Bradford protein assay (Bio-Rad) with BSA as the standard. Proteins were denatured and separated by $12 \%$ SDS-PAGE, and western blot analysis was performed as described previously (Johnson et al. 1999b) using ECL detection (SuperSignal West Pico, Pierce, Rockford, IL, USA) and X-OMAT AR X-ray film (Kodak). Immunoreactive ACP5 protein was detected using affinity purified rabbit anti-ACP5 $(2.5 \mu \mathrm{g} / \mathrm{ml}$; Ellenberger et al. 2008) and SPP1 protein was detected using a cocktail containing rabbit polyclonal antibodies against recombinant human SPP1 (anti-hSPP1; LF-123 and LF-124; $5 \mu \mathrm{g} / \mathrm{ml}$ (Fisher et al. 1995). Rabbit IgG ( $5 \mu \mathrm{g} / \mathrm{ml}$; Sigma) was used as the primary antibody for controls. Multiple exposures of each western blot were performed to ensure linearity of chemiluminescent signals. Western blots were quantified by measuring the intensity of light emitted from correctly sized bands under u.v. light using a ChemiDoc EQ system and Quantity One software (Bio-Rad).

\section{Immunohistochemical analysis}

Immunocytochemical localization of immunoreactive ACP5 in the porcine uterus was performed as described previously (Joyce et al. 2005b) in uterine tissue cross sections using rabbit anti-porcine ACP5 $(4.0 \mu \mathrm{g} / \mathrm{ml}$; Ellenberger et al. 2008). Antigen retrieval for ACP5 was performed by boiling citrate buffer. Negative controls included substitution of the primary antibody with nonimmune rabbit IgG (Sigma Chemical Co.) at the same final concentration.

\section{Statistical analysis}

Data from slot blot hybridization analysis were subjected to least squares ANOVA using the general linear models procedures of the statistical analysis system and were corrected for differences in sample loading using the 18S rRNA data as a covariate. In all analyses, error terms used in tests of significance were identified according to the expectation of the mean squares for error. Slot blot data are presented as least squared means with overall S.E.M. in RU.

\section{Declaration of interest}

The authors declare that there is no conflict of interest that could be perceived as prejudicing the impartiality of the research reported.

\section{Funding}

This project was supported by National Research Initiative Competitive grant no. 2006-35203-17199 from the USDA National Institute of Food and Agriculture. 


\section{References}

Apparao KB, Murray MJ, Fritz MA, Meyer WR, Chambers AF, Truong PR \& Lessey BA 2001 Osteopontin and its receptor $\alpha v \beta(3)$ integrin are coexpressed in the human endometrium during the menstrual cycle but regulated differentially. Journal of Clinical Endocrinology and Metabolism 86 4991-5000. (doi:10.1210/jc.86.10.4991)

Apparao KB, Illera MJ, Beyler SA, Olson GE, Osteen KG, Corjay MH, Boggess K \& Lessey BA 2003 Regulated expression of osteopontin in the peri-implantation rabbit uterus. Biology of Reproduction 68 1484-1490. (doi:10.1095/biolreprod.101.001347)

Basha SM, Bazer FW, Geisert RD \& Roberts RM 1980 Progesteroneinduced uterine secretions in pigs. Recovery from pseudopregnant and unilaterally pregnant gilts. Journal of Animal Science 50 113-123.

Bazer FW, Worthington-White D, Fliss MFV \& Gross S 1991 Uteroferrin: a progesterone-induced hematopoietic growth factor of uterine origin. Journal of Experimental Hematology 19 910-915.

Bazer FW, Wu G, Spencer TE, Johnson GA, Burghardt RC \& Bayless K 2009 Novel pathways for implantation and establishment and maintenance of pregnancy in mammals. Molecular Human Reproduction 16 135-152. (doi:10.1093/molehr/gap095)

Burton GJ, Juaniaux E \& Charnock-Jones DS 2007 Human early placental development: potential roles of the endometrial glands. Placenta $\mathbf{2 8}$ (Supplement A) S64-S69. (doi:10.1016/j.placenta.2007.01.007)

Carson DD, Lagow E, Thathiah A, Al-Shami R, Farach-Carson MC, Vernon M, Yuan L, Fritz MA \& Lessey B 2002 Changes in gene expression during the early to mid-luteal (receptive phase) transition in human endometrium detected by high-density microarray screening. Molecular Human Reproduction 8 871-879. (doi:10.1093/ molehr/8.9.871)

Chen TT, Bazer FW, Centrorelli JJ, Pollard WE \& Roberts RM 1973 Purification and properties of a progesterone-induced basic glycoprotein from the uterine fluids of pigs. Journal of Biological Chemistry 248 8560-8566.

Cooke PS, Buchanan DL, Kurita T, Lubahn DB \& Cunha GR 1998 Stromalepithelial cell communication in the female reproductive tract. In The Endocrinology of Pregnancy, pp 491-506. Ed. FW Bazer. Totowa, NJ: Humana Press.

Dwyer CM, Stickland NC \& Fletcher JM 1994 The influence of maternal nutrition on muscle fiber number development in the porcine fetus and on subsequent postnatal growth. Journal of Animal Science $\mathbf{7 2}$ 911-917.

Ellenberger C, Wilsher S, Allen WR, Hoffmann C, Kolling M, Bazer FW, Klug J, Schoon D \& Schoon HA 2008 Immunolocalisation of the uterine secretory proteins uterocalin, uteroferrin and uteroglobin in the mare's uterus and placenta throughout pregnancy. Theriogenology 15 746-757. (doi:10.1016/j.theriogenology.2008.04.050)

Erikson DW, Burghardt RC, Bayless KJ \& Johnson GA 2009 Secreted phosphoprotein 1 (SPP1, osteopontin) binds to integrin $\alpha \mathrm{v} \beta 6$ on porcine trophectoderm cells and integrin $\alpha v \beta 3$ on uterine luminal epithelial cells, and promotes trophectoderm cell adhesion and migration. Biology of Reproduction 81 814-825. (doi:10.1095/biolreprod.109.078600)

Fisher LW, Stubbs JT III \& Young MF 1995 Antisera and cDNA probes to human and certain animal model bone matrix noncollagenous proteins. Acta Orthopaedica Scandinavica 66 61-65. (doi:10.3109/17453679 509153791)

Garlow JE, Ka H, Johnson GA, Burghardt RC, Jaeger LA \& Bazer FW 2002 Analysis of osteopontin at the maternal-placental interface in pigs. Biology of Reproduction 66 718-725. (doi:10.1095/biolreprod66.3.718)

Geisert RD, Thatcher WW, Roberts RM \& Bazer FW 1982 Establishment of pregnancy in the pig: III. Endometrial secretory response to estradiol valerate administered on day 11 of the estrous cycle. Biology of Reproduction 27 957-965.

Geisert RD, Pratt TN, Bazer FW, Mayes JS \& Watson GH 1994 Immunocytochemical localization and changes in endometrial progestin receptor protein during the porcine oestrous cycle and early pregnancy. Reproduction, Fertility, and Development 6 749-760. (doi:10.1071/ RD9940749)

Girotti M \& Zingg HH 2003 Gene expression profiling of rat uterus at different stages of parturition. Endocrinology 144 2254-2265. (doi:10. 1210/en.2002-0196)
Johnson GA, Spencer TE, Burghardt RC \& Bazer FW 1999a Ovine osteopontin: I. Cloning and expression of mRNA in the uterus during the peri-implantation period. Biology of Reproduction $\mathbf{6 1}$ 884-891. (doi:10.1095/biolreprod61.4.884)

Johnson GA, Burghardt RC, Spencer TE, Newton GR \& Bazer FW $1999 b$ Ovine osteopontin: II. Osteopontin and $\alpha \mathrm{v} \beta 3$ integrin expression in the uterus and conceptus during the peri-implantation period. Biology of Reproduction 61 892-899. (doi:10.1095/biolreprod61.4.892)

Johnson GA, Spencer TE, Burghardt RC, Taylor KM, Gray CA \& Bazer FW 2000 Progesterone modulation of osteopontin gene expression in the ovine uterus. Biology of Reproduction 62 1315-1321. (doi:10.1095/ biolreprod62.5.1315)

Johnson GA, Burghardt RC, Joyce MM, Spencer TE, Bazer FW, Gray CA \& Pfarrer C 2003a Osteopontin is synthesized by uterine glands and a $45-\mathrm{kDA}$ cleavage fragment is localized at the uterine-placental interface throughout ovine pregnancy. Biology of Reproduction 69 92-98. (doi:10.1095/biolreprod.102.013573)

Johnson GA, Burghardt RC, Bazer FW \& Spencer TE 2003b Minireview. Osteopontin: roles in implantation and placentation. Biology of Reproduction 69 1458-1471. (doi:10.1095/biolreprod.103.020651)

Johnson GA, Bazer FW, Burghardt RC, Spencer TE, Wu G \& Bayless KJ 2009 Conceptus-uterus interactions in pigs: endometrial gene expression in response to estrogens and interferons from conceptuses. Society of Reproduction and Fertility Supplement 66 321-332.

Joyce MM, Gonzalez JF, Lewis S, Woldesenbet S, Burghardt RC, Newton GR \& Johnson GA 2005a Caprine uterine and placental osteopontin expression is distinct among epitheliochorial implanting species. Placenta 26 160-170. (doi:10.1016/j.placenta.2004.05.009)

Joyce MM, White FJ, Burghardt RC, Muñiz JJ, Spencer TE, Bazer FW \& Johnson GA 2005b Interferon stimulated gene 15 (ISG15) conjugates to cytosolic proteins and is expressed at the uterine-placental interface throughout ovine pregnancy. Endocrinology 146 675-684. (doi:10.1210/ en.2004-1224)

Joyce MM, Burghardt RC, Geisert RD, Burghardt JR, Hooper RN, Ross JW, Ashworth MD \& Johnson GA 2007 Pig conceptuses secrete estrogen and interferons to differentially regulate uterine STAT1 in a temporal and cell type-specific manner. Endocrinology 148 4420-4431. (doi:10.1210/en. 2007-0505)

Ka H \& Bazer FW 2005 Effects of keratinocyte growth factor on the uterine endometrial epithelial cells in pigs. Asian-Australasian Journal of Animal Sciences 18 1708-1714.

Ka H, Spencer TE, Johnson GA \& Bazer FW 2000 Keratinocyte growth factor: expression by endometrial epithelia of the porcine uterus. Biology of Reproduction 62 1772-1778. (doi:10.1095/biolreprod62.6.1772)

Ka H, Jaeger LA, Johnson GA, Spencer TE \& Bazer FW 2001 Keratinocyte growth factor is up-regulated by estrogen in the porcine uterine endometrium and functions in trophectoderm cell proliferation and differentiation. Endocrinology 142 2302-2310. (doi:10.1210/ en.142.6.2303)

Ka H, Al-Ramadan S, Erikson DW, Johnson GA, Burghardt RC, Spencer TE, Jaeger LA \& Bazer FW 2007 Regulation of fibroblast growth factor 7 expression in the pig uterine endometrium by progesterone and estradiol. Biology of Reproduction 77 172-180. (doi:10.1095/biolreprod.106. 056309)

Kao LC, Tulac S, Lobo S, Imani B, Yang JP, Germeyer A, Osteen K, Taylor RN, Lessey BA \& Giudice LC 2002 Global gene profiling in human endometrium during the window of implantation. Endocrinology 143 2119-2138. (doi:10.1210/en.143.6.2119)

Kensinger RS, Collier RJ, Bazer FW \& Kraeling RR 1986 Effect of number of conceptuses on maternal hormone concentrations in the pig. Journal of Animal Science 62 1666-1674.

Knight JW, Bazer FW \& Wallace HD 1973 Hormonal regulation of porcine uterine protein secretion. Journal of Animal Science 36 546-553.

Knight JW, Bazer FW \& Wallace HD 1974 Effect of progesterone induced increase in uterine secretory activity of development of the porcine conceptus. Journal of Animal Science 39 743-746.

Knight JW, Bazer FW, Thatcher WW, Franke DE \& Wallace HD 1977 Conceptus development in intact and unilaterally hysterectomizedovariectomized gilts: interrelations among hormonal status, placental development, fetal fluids and fetal growth. Journal of Animal Science $\mathbf{4 4}$ 620-637. 
La Bonnardière C, Martinat-Botté F, Terqui M, Lefèvre F, Zouari K, Martal J \& Bazer FW 1991 Production of two species of interferon by Large White and Meishan pig conceptuses during the peri-attachment period. Journal of Reproduction and Fertility 91 469-478. (doi:10.1530/jrf.0. 0910469)

Lefèvre F, Guillomot M, D'Andrea S, Battegay S \& La Bonnardière C 1998 Interferon-delta: the first member of a novel type I interferon family. Biochimie 80 779-788. (doi:10.1016/S0300-9084(99)80030-3)

Nomura S, Wills AJ, Edwards DR, Heath JK \& Hogan BL 1988 Developmental expression of 2ar (osteopontin) and SPARC (osteonectin) RNA as revealed by in situ hybridization. Journal of Cell Biology 106 441-450. (doi:10.1083/jcb.106.2.441)

Perry JS \& Crombie PR 1982 Ultrastructure of the uterine glands of the pig. Journal of Anatomy 134 339-350.

Pope WF 1994 Embryonic mortality in swine. In Embryonic Mortality in Domestic Species, pp 53-78. Eds MT Zavy \& RD Geisert. Boca Raton, FL: CRC Press.

Renegar RH, Bazer FW \& Roberts RM 1982 Placental transport and distribution of uteroferrin in the fetal pig. Biology of Reproduction 27 1247-1260. (doi:10.1095/biolreprod27.5.1247)

Roberts RM \& Bazer FW 1980 The properties, functions and hormonal control of sythesis of uteroferrin, the purple protein of the pig uterus. In Steroid Induced Uterine Proteins, pp 133-149. Ed. M Beato. Amsterdam: Elsevier/North Holland.

Roberts RM \& Bazer FW 1988 The functions of uterine secretions. Journal of Reproduction and Fertility 82 875-892. (doi:10.1530/jrf.0. 0820875)

Ross JW, Ashworth MD, White FJ, Johnson GA, Ayoubi PJ, DeSilva U, Whitworth KM, Prather RS \& Geisert RD 2007 Premature estrogen exposure alters endometrial gene expression to disrupt pregnancy in the pig. Endocrinology 148 4761-4773. (doi:10.1210/en.2007-0599)

Schlosnagle DC, Bazer FW, Tsibris JCM \& Roberts RM 1974 An ironcontaining phosphatase induced by progesterone in the uterine fluids of pigs. Journal of Biological Chemistry 249 7574-7579.
Sinowatz F \& Friess AE 1983 Uterine glands of the pig during pregnancy. An ultrastructural and cytochemical study. Anatomy and Embryology 166 121-134. (doi:10.1007/BF00317948)

Spencer TE, Ing NH, Ott TL, Mayes JS, Becker WC, Watson GH, Mirando MA \& Bazer FW 1995 Intrauterine injection of ovine interferon-tau alters oestrogen receptor and oxytocin receptor expression in the endometrium of cyclic ewes. Journal of Molecular Endocrinology 15 203-220. (doi:10.1677/jme.0.0150203)

Spencer TE, Gray CA, Johnson GA, Taylor KM, Gertler A, Gootwine E, Ott TL \& Bazer FW 1999 Effects of recombinant ovine interferon tau, placental lactogen, and growth hormone on the ovine uterus. Biology of Reproduction 61 1409-1418. (doi:10.1095/biolreprod61.6.1409)

Spencer TE, Johnson GA, Burghardt RC \& Bazer FW 2004 Progesterone and placental hormone actions on the uterus: insights from domestic animals. Biology of Reproduction 71 2-10. (doi:10.1095/biolreprod. 103.024133)

White FJ, Ross JW, Joyce MM, Geisert RD, Burghardt RC \& Johnson GA 2005 Steroid regulation of cell specific secreted phosphoprotein 1 (osteopontin) expression the in the pregnant porcine uterus. Biology of Reproduction 73 1294-1301. (doi:10.1095/biolreprod.105.045153)

Wrana JL, Zhang Q \& Sodek J 1989 Full-length cDNA sequence of porcine secreted phosphoprotein-1 (SPP-1, osteopontin). Nucleic Acids Research 17 10118-10119. (doi:10.1093/nar/17.23.10119)

Young KH, Kraeling RR \& Bazer FW 1990 Effect of pregnancy and exogenous ovarian steroids on endometrial prolactin receptor ontogeny and uterine secretory response in pigs. Biology of Reproduction 43 592-599. (doi:10.1095/biolreprod43.4.592)

Received 5 April 2010

First decision 17 May 2010

Revised manuscript received 7 August 2010

Accepted 12 August 2010 